\title{
The Constraints to a Speedy Trial: The Case of Sidama Zone High Court
}

\author{
Yirgalem Germu Berega \\ Hawassa University, Hawassa, Ethiopia \\ Email: yirgalemg45@gmail.com
}

How to cite this paper: Berega, Y. G. (2018). The Constraints to a Speedy Trial: The Case of Sidama Zone High Court. Beijing Law Review, 9, 162-184. https://doi.org/10.4236/blr.2018.92012

Received: January 4, 2018

Accepted: May 12, 2018

Published: May 15, 2018

Copyright $\odot 2018$ by author and Scientific Research Publishing Inc. This work is licensed under the Creative Commons Attribution International License (CC BY 4.0).

http://creativecommons.org/licenses/by/4.0/ (c) (i) Open Access

\begin{abstract}
The general objective of this study is to appraise the enforcement of the right of accused persons to speedy trial in the Sidama Zone; specifically, to find out the organ responsible for the violation of the right, the courts as an institution or individual judges, to pinpoint the measures that can be taken to enforce the right to speedy trial, and to assess the interpretive approaches adopted for "reasonable time" by courts. From unnecessarily given adjournments of the selected cases five major of reasons for the delay of trial are identified: reasons related with the court, reasons related with the police and the public prosecutors, reasons related with the accused, reasons related with prisons and unsuccessful restorative justice system. The result shows that the court renders judgment in a speedy manner for appeal cases because it gives very short adjournments with fewer adjournments in number. However, with respect to direct suits: the writer concludes that the Sidama Zone High Court is not delivering speedy trial for its clients.
\end{abstract}

\section{Keywords}

Speedy Trial, Courts, Adjournment, Sidama Zone High Court

\section{Introduction}

All human beings are born equal in dignity and rights. They by virtue of their being human, possess certain basic and inalienable rights which are commonly known as human rights. Since these rights belong to them because of their very existence, they become operative with their birth. These rights, being birthright, are, therefore, inherent in all individuals irrespective of their difference on cer- 
tain grounds, such as race, religion, nationality etc. ${ }^{1}$ They are essential for individuals as they are related with their freedom and dignity, and are conductive to physical, moral, social and spiritual welfare.

Everyone shall be entitled "to be tried without undue delay". The assessment of what may be considered undue delay will depend on the circumstances of a case, i.e. its complexity, the conduct of the parties, whether the accused is in detention, etc. The right is, however, not contingent on a request by the accused to be tried without undue delay. ${ }^{2}$

A "speedy" trial basically means that the defendant is tried for the alleged crimes within a reasonable time after being arrested. ${ }^{3}$ The right to a speedy trial keeps defendants from sitting in jail for an indefinite period before trial. It also improves the chances that an adequate defense can be prepared. If a trial is delayed for a long time then witnesses may start to disappear, evidence may be lost or destroyed and memories may fade. ${ }^{4}$

Faith in the judicial system is determined by its ability to provide accessible, speedy and cost-effective justice to all equally. It is a fundamental right of every citizen to get speedy justice, which also is the basic requisite of good judicial administration. ${ }^{5}$ As applied to a criminal trial, denial of due process is the failure to observe that fundamental fairness which is essential to the very concept of justice. ${ }^{6}$ The ability of the judicial system to provide speedy trial depends upon its institutional capacity, which comprises, inter alia, the qualification and experience of personnel.

The researcher conducted the study so as to identify the prevailing condition of the right to speedy trial, along with the existing problems in the area, for that reason the existing laws and the practice examined, with due consideration of the cases entertained by Sidama Zone High Court and Hawassa City High Court, in South Nation Nationalities Peoples Regional State (SNNPRS). ${ }^{7}$ And the researcher has done the task to find out the measures that have to be taken, so as to protect speedy trial right of individuals.

${ }^{1}$ Please read the preamble of the following International Human Right Instruments

- Universal Declaration on Human Rights, declared on Dec. 10/1948.

- International Covenant on Economic, Social and Cultural Rights, G.A. res. 2200A (XXI), 21 U.N. 1966 entered in to force Jan.3/1976.

- International Covenant on Civil and Political Rights, G.A. res. 2200A (XXI), 21 U.N. 1966 entered in to force March 13/1976, Hereinafter ICCPR.

${ }^{2}$ Lawyers Committee for Human Rights, What Is A Fair Trial? A Basic Guide to Legal Standards and Practice, March 2000, p. 16 available on http://www.lchr.org, Retrieved on Dec. 20/2015 at 4:20 am.

${ }^{3}$ Right to a Speedy Jury Trial—FindLaw.html. Retrieved on Jan.11/2016 at 5:00 am.

${ }^{4}$ Defendant's Right to a Speedy Trial-Lawyers.com.html, Retrieved on Dec. 20/2015 at 4:20 am.

${ }^{5}$ http://www.americanbar.org/publications/criminal_justice_section_archive/crimjust_standards_spe edytrial_blk.html, accessed on January 12, 2016, 3:00 AM.

${ }^{6} J u d g e$ Patrick Robinson, The Right to a Fair Trial in International Law: with Specific Reference to the Work of the ICTY, Vol. 3, Berkeley J.L Int'l L. Publicist, 2009, p. 3.

${ }^{7}$ This two courts are located in Hawassa City, South Nation Nationalities and Peoples Regional State, Ethiopia. The two courts apply similar justice system and laws of the particular state and the country. The difference is language of adjudication: while Sidama Zone High Court applies "Sidamigna" language, Hawassa City High Court adjudicates in Amharic language. 


\section{Significance of the Study}

As mentioned above, the paper is intended to identify the main problems and gaps in the protection of speedy trial right. In relation to this, the researcher hope that it will pave the way to study the implementation of constitutional provisions of the right and the necessity of legal regime to control the justice system in a way that helps to guarantee the protection of the rights. Additionally, the paper may encourage further study on the area, in concrete manner.

\section{Methodology and Methods}

In conducting this research, the researcher employed related human right instruments, including Ethiopian constitution and the constitution of SNNPRS. And also interviews conducted with policemen, judges and individuals from prisons and police stations as well. Finally, the researcher analyzed some selected cases that were entertained at the court, in light with the issue at hand.

\section{1) Target population}

The study focused on the courts and other justice institutions that involved in the detention of individuals and entertaining criminal cases. Under the research, Sidama Zone High Court and some selected police stations found in Hawassa City and around the city have been assessed.

\section{2) Sampling technique and sampling size}

Since taking all the target population in prisons and police stations is time consuming and costly, random sampling has been employed to obtain representative sample size and then primary data was collected from the selected courts and individuals at prison and police stations.

\section{3) Types and sources of data}

In this study both primary and secondary data as a source of information are employed. The main sources of primary data are gathered from court documents, the secondary data also including prisoner ${ }^{8}$ and judges ${ }^{9}$. On the other hand, the main source of secondary data are scholarly materials which deals with the area which the researcher going to conduct the research.

\section{4) Methods of data collection}

The primary data of the research has been collected in a questionnaire and interview. The questionnaires are both open ended and close ended questions, to get the required data.

\section{5) Methods of data analysis}

The collected data has been presented by using tables and percentages. Then it analyzed using the legal concepts that dealt throughout the paper.

\section{Speedy Trial}

\subsection{The Notion of Speedy Trial}

Speedy trial: a trial that the prosecution, with reasonable diligence, begins ${ }^{8}$ The researcher employed a questioner at prison and 110 prisoners were participant for that matter. ${ }^{9}$ On some issues related with court work, interview has been conducted with the president of high court and public prosecutor at Sidama Zone High Public prosecutor's Office. 
promptly and conducts expeditiously. In deciding whether an accused has been deprived of that right, courts generally consider the length of the delay the reason for the delay, and the prejudice to the accused. ${ }^{10}$

To begin with, a government prosecutor may not delay the trial of a criminal suspect arbitrarily and indefinitely. Otherwise, the neglect of impose such delays would allow prosecutors to effectively send anyone to jail for an arbitrary length of time. In jurisdictions with strong rule of law, the requirement of a "speedy trial" forces prosecutors to diligently build cases within a reasonable amount of time commensurate with the complexity and heinousness of the crimes of which suspects are accused. It is based on the notion that long-term incarceration is to be normally restricted to situations where a judge determines a suspect has committed a crime specifically enumerated in a statute. ${ }^{11}$

Additionally, speedy trial is a trial that the prosecution, with reasonable diligence, begins promptly and conducts expeditiously. ${ }^{12}$ In the determination of any criminal charge against him, everyone shall be entitled " $[t]$ o be tried without undue delay"13. The time limit "begins to run when the suspect (accused, defendant) is informed that the authorities are taking specific steps to prosecute him." ${ }^{14}$

The assessment of what may be considered undue delay will depend on the circumstances of a case, i.e. its complexity, the conduct of the parties, whether the accused is in detention, etc. The right is, however, not contingent on a request by the accused to be tried without undue delay. ${ }^{15}$

Some scholars argued that "the right to a speedy trial does not apply to every stage of a criminal case. It arises only after a person has been arrested, indicted, or otherwise formally accused of a crime by the government. Before the point of formal accusation, the government is under no rendering speedy trial obligation to investigate, accuse, or prosecute a defendant within a specific amount of time." ${ }^{16}$ This line of argument is supported by the Human Rights Committee which states that "[t]his guarantee (trial without undue delay) relates not only to the time by which a trial should commence, but also the time by which it should end and judgment be rendered; all stages must take place "without undue delay." ${ }^{\prime 17}$ The word "commence" in the General Comment implies that article 14(3)

\footnotetext{
${ }^{10}$ Bryan A. Garner (ed.), Black's Law Dictionary, West Group, $7^{\text {th }}$ ed. (1999), p. 1408.

${ }^{11}$ https://en.wikisource.org/wiki/Constitution_of_the_Philippines_(1987)\#Article_III_Bill_of_Rights, accessed on January 12, 2016, 3:18 AM.

${ }^{12}$ Bryan A. Garner (ed.), Black's Law Dictionary, West Group, $7^{\text {th }}$ ed. (1999), p. 1408.

13ICCPR, Art. 14(3) (c)

${ }^{14}$ Manfred Nowak, U.N. International Covenant on Civil and Political Rights, ICCPR Commentary (N.P. Engel, Arlington (1993) (hereinafter Nowak Commentary), p. 257.

${ }^{15}$ Lawyers Committee for Human Rights, What Is A Fair Trial? A Basic Guide to Legal Standards and Practice, March 2000, p. 16, available at http://www.lchr.org accessed on January 12, 2016, 3:08 AM.

${ }^{16}$ Gerald N. Hill and Kathleen T. Hill, Legal Definition of Speedy Trial,

http://www.thefreedictionary.com/_/WoD/rss.aspx, accessed on January 12, 2016, 3:20 AM.

${ }^{17}$ Human Rights Committee, General Comment 13, Article 14 (Twenty-first session, 1984), Compilation of General Comments and General Recommendations Adopted by Human Rights Treaty Bodies, U.N. Doc. HRI/GEN/1/Rev.1 at 14 (1994). [emphasis added] Art. 10.
} 
(c) of the ICCPR governs the beginning of trial without undue delay, which means, states are under obligation to ensure the protection of suspects from incarceration for unreasonable time before the beginning of the trial, this scenario includes confinement in police stations after the appearance of the suspect before a court to ensure the lawfulness of the detention.

\subsection{Analysis on Practical Reasons for Delay and Commentary on Selected Cases}

\subsubsection{Introductory Remarks}

This part of the paper is devoted for the analysis of practical reasons for delay and commentary on selected cases, the writer prefers to deal with the practical reasons for the delay in the justice system, the case of Sidama Zone High Court, in particular, and also comparison with Hawassa City High Court is made.

There has been a survey to assess the reflection of the general public residing in Hawassa on the issue of speedy trial. The survey has been conducted in ten kebeles of the city. ${ }^{18}$ among 275 residents, selected randomly, 30 from each kebele who live in every third house in the respective kebeles, 156 of them responded that the court system takes a long time to dispose cases, 59 of them responded that the court system doesn't take a long time for the final disposition of the case and the remaining 60 respondent said I do not know about the court system with respect to the issue raised, speedy trial. As per this result $56.72 \%$ of the respondents believe that there is delay in the court system, $21.45 \%$ responded for the existence of speedy trial and the remaining $21.81 \%$ of them did not know.

The data employed under this chapter is collected from the cases entertained by the two courts, questionnaires from Hawassa Prison and interview with member of the public prosecutor and the president of the High court of Sidama Zone.

This section has three different, but related parts, the first one deals with the reasons for the delay in the justice system, the second one deals with commentary on the selected cases of Sidama Zone High court, in comparison with Hawassa City High Court and the third one shows the performance of Sidama Zone High Court, under randomly selected cases.

\subsubsection{Reasons for the Delay}

From unnecessarily given adjournments of the selected cases five source of reasons for the delay of trial are identified under this sub-section: Reasons Related with the Court, which comprises 10.59\% in Sidama Zone High Court and 9.62\% in Hawassa City High Court; reasons related with the police and the public prosecutors, which comprises 60\% in Sidama Zone High Court and 63.46\% in Hawassa City High Court; reasons related with the accused, which comprises $11.76 \%$ in Sidama Zone High Court and $15.38 \%$ in Hawassa City High Court; reasons related with prisons, which comprises $16.47 \%$ in Sidama Zone High ${ }^{18}$ This survey has been conducted for the purpose of the research conducted under the supervision of Ato Yidnekachew Ayele, head of Hawassa university law school and I and other my class mates has been the enumerators of the survey. Thank you Ato Yidnekachew for your permission. 
Court and 9.62\% in Hawassa City High Court and other, unsuccessful restorative justice system, which comprises $1.18 \%$ in Sidama Zone High Court and 1.92\% in Hawassa City High Court.

Table 1 provides that the share of each organ for the delay cases under the selected cases and as mentioned above the office of public prosecutors and police takes the lion share. ${ }^{19}$

\section{1) Reasons Related with the Court}

Under this sub-section the writer deals with: Lack of Proportionality between Number of Cases and Number of Personnel in the Court; meetings on working hours; forgetting to make a decision while the case is adjourned for that purpose; Failing to follow the Procedural Laws Appropriately and failing to transcribe the recorded voice of witnesses, are raised as the reasons for delay of justice because of courts problem. The problems are identified by looking into 40 dead files, 20 from Sidama Zone High Court and 20 from Hawassa City High Court, and the information gathered from prisoners and suspects under structured questionnaires. From the selected cases meetings on working time, failing to transcribe the recorded voice of witnesses and forgetting to make a decision while the case is adjourned for that purpose are identified as the reasons for the delay and the remaining reasons are from the questionnaires.

Under the selected 40 case there are 315 adjournments, among this 164 in Sidama Zone High Court and the remaining 151 adjournments in Hawassa City High Court. From these adjournments 14 of them are adjourned because of the courts problem, 9 of this by Sidama Zone High Court and 5 from Hawassa City High Court. $10.59 \%$ of adjournments made under Sidama Zone High Court cases are related with the court itself and $9.62 \%$ of adjournments made under Hawassa City High Court cases are the problems of the court.

a) Lack of Proportionality between Number of Cases and Number of Personnel in the Court

Sidama Zone High Court is situated in Hawassa City and it holds the first instance courts of 19 woredas and 4 city administrations. The court receives 554 direct cases and 920 appeal cases in 2006 E.C, 644 direct cases and 843 appeal

Table 1. Reasons for the delay of cases at Sidama Zone High Court and Hawassa City High Court.

\begin{tabular}{ccc}
\hline No. & $\begin{array}{c}\text { Share at Sidama Zone High } \\
\text { Court (\%) }\end{array}$ & $\begin{array}{c}\text { Share at Hawassa } \\
\text { City High Court (\%) }\end{array}$ \\
\hline 1) Prisons & 16.47 & 9.62 \\
2) Court & 10.59 & 9.62 \\
3) Public prosecutors and police & 60 & 63.46 \\
4) The accused & 11.76 & 15.38 \\
5) Others & 1.18 & 1.92 \\
\hline
\end{tabular}

${ }^{19}$ Table 1: Reasons for the delay of cases at Sidama Zone High Court and Hawassa City High Court, information gathered from the cases collected from the courts. 
cases in 2007 E.C and 549 direct cases and 650 appeal cases in 2008 E.C, until Megabit 30, the seventh month of Ethiopian calendar. This means on average the court receives 635.27 direct suits and 877.45 appeal cases per year, totally 1512.72 cases per year. On the other hand Hawassa City High Court receives 654 direct cases and 251 appeal cases in 2006 E.C, 780 direct cases and 223 appeal cases in 2007 E.C and 516 direct cases and 166 appeal cases in 2008 E.C, until Megabit 30, the seventh month of Ethiopian calendar. This means on average the court receives 709.09 direct suits and 232.72 appeal cases per year, total 941.81 cases per year. When we compare the number of case received by the two courts, the average number of cases received by Sidama Zone High Court in the last three years is, including this year, exceeds the City High Court by 644.73 appeal cases. But, the City High Court exceeds the Zone Court by 73.82 direct suits, the total cases more received by the Sidama Zone High Court are $570.91^{20}$

When we compare the number of employees in the two courts: Sidama Zone High Court have 10 judges 3 judgment officers and 48 others (including assistant judgment officers, guards, office clerks, etc.). Hawassa City High Court has 15 judges 6 judgment officers, and 42 others (including assistant judgment officers, guards, office clerks, etc.). ${ }^{21}$

For better comparison, it is better to divide the average number of cases received by the courts for the total number of judges in each court and the total number of judgment officers in each court. In the Sidama Zone High Court totally 151.27 direct suits and appeal case are entertained by one judge per year. But in Hawassa City High court 62.78 direct suits and appeal case are entertained by one judge per year. On the other hand in the Sidama Zone High court 504.24 direct suits and appeal case are examined by one judgment officer per year. But in Hawassa City High court 156.97 direct suits and appeal case are examined by one judgment officer per year. Therefore, to make the cases entertained by judges in the two courts equal the Sidam Zone High Court shall recruit additional 14.09 judges and 6.63 judgment officers, ceteris paribus.

The president of Sidama Zone High Court also believe that the number of "the judges available in the court are not sufficient" and he said that "the number of judges indicated under the BPR document are very insufficient and it did not considered the actual need of the court and the number of appeals being entertained by the court." ${ }^{22}$

\section{b) Meetings on Working Hours}

Handling a meeting on working hours is the general problem of this country, as per the view of the writer of this paper, and courts as government wings are not free from this problem. In a survey made on the above stated 40 cases there

\footnotetext{
${ }^{20}$ The number of the direct suits and appeal cases are gathered from the information centers of the two courts on the date of May 28, 2016.

${ }^{21}$ The number of employees in the two courts gathered from the office of human resource and information centers of the two courts, on the date of May 30, 2016.

${ }^{22}$ Interview with AtoGiremaGoye Share, the president of Sidama Zone High Court, interview conducted at the office of the President, Sidama Zone High Court, Hawassa, 30 May 2016 at 5:00, hereinafter AtoGirma Goye Share.
} 
are 9 adjournments made because of meetings out of 315 adjournments, from this 7 of the meetings are the share of Sidama Zone High Court and the remaining 2 takes Hawassa City High Court.

$10.59 \%$ of adjournments made under Sidama Zone High Court cases are related with the court itself and $9.62 \%$ of adjournments made under Hawassa City High Court cases are the problems of the court itself. Which means $77.78 \%$ of the reasons for adjournment related with the court's problem under the 20 cases of Sidama Zone High Court are arise from the meetings. And $40 \%$ of the reasons for adjournment related with the court's problem under the 20 cases of Hawassa City High Court are arising from the meetings.

c) Forgetting to Make a Decision While the Case Is Adjourned for That Purpose

Courts may adjourn a case for different reasons and they are expected to perform the act which is required to be done by them. However, the selected cases revealed that the existence of certain conditions where court failed to do so. Among the above 315 adjournments of the 40 cases the three (3) adjournments are related with forgetting to make a decision while the case is adjourned for that purpose, the 2 from Sidama Zone High Court cases and 1 of this from Hawassa City High Court cases. This shows that $22.22 \%$ of the reasons for adjournment related with the court's problem under the 20 cases of Sidama Zone High Court are arise from forgetting to make a decision while the case is adjourned for that purpose. And $20 \%$ of the reasons for adjournment related with the court's problem under the 20 cases of Hawassa City High Court are arise from this reason.

\section{d) Failing to Apply the Procedural Laws Appropriately}

As provided under article 94(2) of the Criminal Procedure Code an adjournment may not be granted unless 1) the prosecutor, public or private, or the accused fails for good cause to appear: this condition occurs many times, this is part of discussion under the following sub-sections, but courts resort to "interests of justice so require", which is sated under article 94(1) of the code 2) Witnesses for the prosecution or the defense are not present: under this requirement the law sated no requirement, such as good cause requirement employed under sub article a. but, article 95(2) states that "where the purpose for which the adjournment was granted has not been carried out for a reason not attributable to the fault of the prosecution or the defense, a further adjournment of the same or less duration shall be granted." This provision allows adjournment only when the reason for the failure is "not attributable to the fault of the prosecution or the defense". However, courts adjourn many cases on the ground of 'interests of justice” provided under article 94(1), as far as the writer's knowledge concerned this is inappropriate. $19.09 \%$ of prisoners, 21 out of 110 respondents of the questionnaires, in Hawassa Prison whose case is disposed by Sidama Zone High Court believe that their case has been delayed because the judges failed to apply the procedural laws appropriately.

e) Failing to Transcribe the Recorded Testimony of Witnesses 
This is the only reason identified in the 40 cases which is available only under the 20 cases of Hawassa City High Court; in no part of Sidama Zone High Court cases mentioned such a problem. Out of 156 adjournments failing to transcribe the recorded voice of witnesses takes the 2 . This means failing to transcribe the recorded voice of witnesses makes $40 \%$ of the reason for delay related with the court itself.

\section{f) Other Court Related Reasons}

Incompetence of judges: this ground can be seen in light of the decided cases and academic achievement of the judges at the court. The president of Sidama Zone High Court argues that "there is no incompetence among our judges, because among the 10 judges 8 have first degree and 5 years and more experience on works directly related with law, especially there are members of judgeship who has been public prosecutors and this helps them to deal with cases easily. And the remaining 2 judges got their master's degree with relevant experience". ${ }^{23}$ On the other hand, $19.09 \%$ of prisoners, 21 out of 110 responses of the questionnaires, in Hawassa Prison whose case is disposed by Sidama Zone High Court believe that their case has been delayed because the judges are incompetent to entertain the case.

Corruption and other unethical practices: this ground is difficult to prove with the help of cases and interview with the officials because corruption and similar practices are not apparent by their nature and the writer believe that no one, among the judges, may admit his unethical conduct for the purpose of a research. But, the ground has been stated under the questionnaire distributed for the prisoners at Hawassa prison. As per the result $45.45 \%$ of prisoners, 50 out of 110 responses of the questionnaires, in Hawassa Prison whose case is disposed by Sidama Zone High Court believe that their case has been delayed because there is corruption and unethical conduct.

Table 2 of the writing consists of data on the reasons associated with the adjudicating courts for the delay of cases. ${ }^{24}$

2) Reasons Related with Police Stations and Office of Public Prosecutor

Under this sub-section the writer deals with: failing to bring the accused before the court; failing to produce an evidences/witness; failing to conclude the investigation; failing to give idea whenever required by the court; non-appearance on adjournments; and failing to provide there cord of public prosecutor, are raised as the reasons for delay of justice because of problems related with the police and the office of public prosecutors. The problems are identified by looking into 40 dead files, 20 from Sidama Zone High Court and 20 from Hawassa City High Court, and the information gathered from prisoners and suspects under structured questionnaires. All the reasons are identified from the cases mentioned.

Under the selected 40 case there are 315 adjournments, among this 164 in ${ }^{23}$ AtoGirmaGoye Share.

${ }^{24}$ Table 2: Reasons related with the courts, the information is obtained from the statements written by judges in each files of the cases. 
Table 2. Reasons related with the courts.

\begin{tabular}{|c|c|c|c|c|}
\hline \multirow{2}{*}{$\begin{array}{l}\text { The reasons for the delay identified from the } \\
\text { selected cases }\end{array}$} & \multicolumn{2}{|c|}{$\begin{array}{l}\text { The given adjournment in } \\
\text { number }\end{array}$} & \multicolumn{2}{|c|}{$\begin{array}{c}\text { Percentage } \\
\text { from unnecessary } \\
\text { adjournments }\end{array}$} \\
\hline & Sidama ZHC & $\begin{array}{l}\text { Hawassa } \\
\text { HC }\end{array}$ & $\begin{array}{l}\text { Sidama } \\
\text { ZHC }\end{array}$ & Hawassa HC \\
\hline 1) meetings on working hours & 7 & 2 & $8.23 \%$ & $3.85 \%$ \\
\hline $\begin{array}{l}\text { 2) forgetting to make a decision while } \\
\text { the case is adjourned for that purpose }\end{array}$ & 2 & 1 & $2.35 \%$ & $1.92 \%$ \\
\hline $\begin{array}{l}\text { 3) failing to transcribe the recorded } \\
\text { voice of witnesses }\end{array}$ & -- & 2 & -- & $3.85 \%$ \\
\hline
\end{tabular}

Sidama Zone High Court and the remaining 151 adjournments in Hawassa City High Court. From these adjournments 84 of them are adjourned because of the police and public prosecutor, 51 of this under the cases entertained by Sidama Zone High Court and 33 available under the cases of Hawassa City High Court. $60 \%$ of adjournments made under Sidama Zone High Court cases are related with the police and public prosecutor and $63.46 \%$ of adjournments made under Hawassa City High Court cases are the problems of the police and public prosecutor. The aforementioned reasons are elaborated hereinafter:

\section{a) Failing to Bring the Accused before the Court}

As provided under the Criminal Procedure Code: the public prosecution department may in the discharge of its duties give the necessary orders and instructions to the police and ensure that the police carry out their duties in accordance with law. And the police shall in accordance with the Code assist the public prosecution department in: preserving the peace and preventing crime; discovering the commission of offences; apprehending offenders; and prosecuting offences when members of the police are appointed as public prosecutors. ${ }^{25}$ However, the two departments are being the cause for the many adjournments because of their failure to bring the accused person before the court. Among the 315 adjournments the 37 are adjourned only for this reason, 13 at Hawassa City High Court and 24 at Sidama Zone High Court. This means $47.05 \%$ of the reasons for adjournment related with the problem of police and public prosecutor under the 20 cases of Sidama Zone High Court are arise from failing to bring the accused before the court. And $39.39 \%$ of the reasons for adjournment related with these organs under the 20 cases of Hawassa City High Court are arising from this reason.

\section{b) Failing to Produce an Evidences/Witness}

Among the above 315 adjournments of the 40 cases the 32 adjournments are related with forgetting to make a decision while the case is adjourned for that purpose, 16 from each courts. This shows that $31.37 \%$ of the reasons for adjournment related with the problem of police and public prosecutor under the 20 cases of $\mathrm{Si}$ dama Zone High Court are arise from failing to produce an evidences/Witness.

${ }^{25}$ Criminal Procedure Code of Ethiopia, Negarit Gazeta (Extraordinary Issue), No. I of 1961, Proclamation No.185/1961, Art. 8(2) and 9. 
And $48.48 \%$ of the reasons for adjournment related with these organs' under the 20 cases of Hawassa City High Court are arising from this reason.

\section{c) Other Reasons Related with Public Prosecutor}

Among 51 adjournments in Sidama Zone High Court cases and 33 adjournments in Hawassa City High Court cases, the following reasons takes their own share: failing to conclude the investigation $9.8 \%$, failing to give an idea whenever required by the court and $5.88 \%$ failing to provide the record of public prosecutor $1.96 \%$, of the 51 adjournments of Sidama Zone High Court, none of these reasons are available under the selected 20 cases of Hawassa City High Court. Additionally, non-appearance of the public prosecutor on adjournments holds $3.92 \%$ and $12.12 \%$ of the adjournments, in Sidama Zone High Court and Hawassa City High Court, respectively, made because of the problems related with police and the public prosecutor.

As we examined the problems many of the reasons raised from office of public prosecutors and the police. However, Ato Yalew Tsekeste, argues that the public prosecutor office is working in a manner that helps to protect speedy trial right of the accused. As per his opinion, the measurement for the speedy trial are accessibility, working with the police department intimately, increasing number of human resource in each Woreda to execute the duty of the office and successive reports helps to remember each records of the public prosecutor. ${ }^{26}$

Table 3 indicates that the reasons that make the Police Stations and Office of Public Prosecutor to delay cases. ${ }^{27}$

\section{3) The Reasons Related with the Accused}

When there is a delay of a case or one case adjourned many times affects the time of the court and increase the burden of a judge this in turn affects the speedy trial right of the other accused whose case is being entertained under other file.

Table 3. Reasons related with police stations and office of public prosecutor.

\begin{tabular}{|c|c|c|c|c|}
\hline \multirow{2}{*}{$\begin{array}{l}\text { The reasons for the delay identified from } \\
\text { the selected cases }\end{array}$} & \multicolumn{2}{|c|}{$\begin{array}{c}\text { The given } \\
\text { adjournment in } \\
\text { number }\end{array}$} & \multicolumn{2}{|c|}{$\begin{array}{c}\text { Percentage } \\
\text { FROM UNNECESSARY } \\
\text { ADJOURNments }\end{array}$} \\
\hline & Sidama ZHC & $\begin{array}{c}\text { Hawassa } \\
\text { HC }\end{array}$ & $\begin{array}{c}\text { Sidama } \\
\text { ZHC }\end{array}$ & Hawassa HC \\
\hline 2.1. failing to bring the accused before the court & 24 & 13 & $28.24 \%$ & $25 \%$ \\
\hline 2.2. failing to produce an evidences/witness & 16 & 16 & $18.82 \%$ & $30.77 \%$ \\
\hline 2.3. failing to conclude the investigation & 5 & -- & $5.88 \%$ & -- \\
\hline $\begin{array}{l}\text { 2.4. failing to give idea whenever required by the } \\
\qquad \text { court }\end{array}$ & 3 & -- & $3.53 \%$ & -- \\
\hline 2.5. non-appearance on adjournments & 2 & 4 & $2.35 \%$ & $7.69 \%$ \\
\hline $\begin{array}{l}\text { 2.6. failing to provide the record of } \\
\text { public prosecutor }\end{array}$ & 1 & -- & $1.18 \%$ & -- \\
\hline
\end{tabular}

${ }^{26}$ Interview with AtoYalewTsekeste, Public Prosecutor at Sidama Zone Justice Office, interview conducted at the office of public prosecutors, Hawassa, 19 May 2016, at 3:00 AM.

${ }^{27}$ Table 3: Reasons Related with Police Stations and Office of Public Prosecutor, the collected cases from the courts are the source of information in the table. 
10 of the 164 adjournments given by Sidama Zone High Court are given because of the reasons related with the accused; this comprises $11.76 \%$ of the unnecessary adjournments. 8 of the 151 adjournments given by Hawassa City High Court are given because of the reasons related with the accused; this comprises $15.38 \%$ of the unnecessary adjournments. The reasons related with the accused himself hold the following percentage: the non-appearance of co-offender 30\%; non-appearance of defense witnesses $30 \%$; others $20 \%$ of the 10 unnecessary adjournments of Sidama Zone High Court. Additionally, Courts need the submission of extenuating circumstances so as to determine the sentence against the accused. ${ }^{28}$ But as inferred from the 20 cases of Sidama Zone High Court the accused fails to submit the grounds that may help him in the determination of the sentence, this is $30 \%$ of the unnecessary adjournments related with the accused. The only reason, related with the accused, available in the 20 cases of Hawassa City High Court is failing to produce defense evidences.

Table 4 of the writing deals with the reasons contributed by the accused for the delay of cases. ${ }^{29}$

\section{4) Reasons Related with Prisons}

Prisons are also one of the organs accountable in the dalliance trials, 14 of adjournments among the 85 unnecessary adjournments given by Sidama Zone High Court are the result of failing to make available the accused, who is under their custody, this number holds $16.47 \%$ of the unnecessary adjournments of the court.

Table 5 provides an information on the reasons for delay which is associated with prisons. ${ }^{30}$

Table 4. The reasons related with the accused.

\begin{tabular}{|c|c|c|c|c|}
\hline \multirow{2}{*}{$\begin{array}{l}\text { The reasons for the delay identified from } \\
\text { the selected cases }\end{array}$} & \multicolumn{2}{|c|}{$\begin{array}{l}\text { The given adjournment in } \\
\text { number }\end{array}$} & \multicolumn{2}{|c|}{$\begin{array}{c}\text { Percentage } \\
\text { from unnecessary } \\
\text { adjournments }\end{array}$} \\
\hline & Sidama ZHC & $\begin{array}{c}\text { Hawassa } \\
\text { HC }\end{array}$ & $\begin{array}{c}\text { Sidama } \\
\text { ZHC }\end{array}$ & Hawassa HC \\
\hline 3.1. non-appearance of co-offender & 3 & -- & $3.53 \%$ & -- \\
\hline 3.2. failing to produce defense evidences & 3 & 8 & $3.53 \%$ & $15.38 \%$ \\
\hline 3.3. other reasons & 4 & -- & $4.71 \%$ & -- \\
\hline
\end{tabular}

Table 5. Reason related with prisons.

\begin{tabular}{|c|c|c|c|c|}
\hline \multirow{2}{*}{$\begin{array}{l}\text { The reasons for the delay identified } \\
\text { from the selected cases }\end{array}$} & \multicolumn{2}{|c|}{$\begin{array}{l}\text { The given } \\
\text { adjournment in number }\end{array}$} & \multicolumn{2}{|c|}{$\begin{array}{c}\text { Percentage } \\
\text { from unnecessary } \\
\text { adjournments }\end{array}$} \\
\hline & Sidama ZHC & $\begin{array}{c}\text { Hawassa } \\
\text { HC }\end{array}$ & $\begin{array}{c}\text { Sidama } \\
\text { ZHC }\end{array}$ & Hawassa HC \\
\hline Failing to make available the accused & 14 & 5 & $16.47 \%$ & $9.62 \%$ \\
\hline \multicolumn{5}{|c|}{$\begin{array}{l}{ }^{28} \text { The Criminal Code of the Federal Democratic Republic of Ethiopia, the Federal Negarit Gazeta } \\
\text { Yr. } 10 \text { No. -, Proc. No. } 414 / 2004,9^{\text {th }} \text { May, } 2005 \text {, Art. } 82 \text {. }\end{array}$} \\
\hline \multicolumn{5}{|c|}{$\begin{array}{l}{ }^{29} \text { Table 4: The reasons related with the accused, the collected cases from the courts are the source of } \\
\text { information in the table. }\end{array}$} \\
\hline
\end{tabular}




\section{5) Others}

Under this category failed/unsuccessful restorative justice mechanisms are incorporated. In a few cases entertained by the two courts such ground is being the reason for the delay of the trial. This comprises $1.18 \%$ and $1.92 \%$ of the unnecessary adjournments given by Sidama Zone high Court and Hawassa city High Court, respectively.

Table 6 of the paper reveals the contribution of Unsuccessful Restorative Justice in the delay of cases. ${ }^{31}$

Table 7 provides an information about the cases examined and identified unnecessary adjournments, because of the reasons provided herein above, by doing so the table reveals that the actual adjournments sufficient to render the final judgment, if the unnecessary reasons for delay of case have been not happened. ${ }^{32}$

\subsubsection{Overview of Selected Cases}

Under this section three cases entertained by Sidama Zone High Court are examined for the purpose of the commentary, the cases are selected randomly.

File No. 37976

Date of file instituted 07//04/08E.C.

Judgment rendered: 30/07/08E.C.

Public Prosecutor Vs. Woinshet Ganyale and Birke Ganyale

The defendants are accused for murder case under article 540 of the criminal code.

Table 6. Other reasons of the delay in trials.

\begin{tabular}{ccccc}
\hline \multirow{2}{*}{$\begin{array}{c}\text { The reasons for the delay } \\
\text { identified from the selected cases }\end{array}$} & $\begin{array}{c}\text { The given adjournment in } \\
\text { number }\end{array}$ & from unnecessary adjournments \\
\cline { 2 - 5 } & Sidama ZHC & Hawassa HC & Sidama ZHC & Hawassa HC \\
\hline Unsuccessful Restorative Justice & 1 & 1 & $1.18 \%$ & $1.92 \%$ \\
\hline
\end{tabular}

Table 7. The number of cases examined and adjournment given thereof.

\begin{tabular}{|c|c|c|c|c|}
\hline \multirow{2}{*}{ No. } & & \multicolumn{2}{|c|}{ Name of the Court } & \multirow[b]{2}{*}{ Total } \\
\hline & & $\begin{array}{l}\text { Sidama Zone High } \\
\text { Court }\end{array}$ & $\begin{array}{c}\text { Hawassa City } \\
\text { High Court }\end{array}$ & \\
\hline 1 & Number of cases examined & 20 & 20 & 40 \\
\hline 2 & $\begin{array}{l}\text { Number of total adjournment } \\
\text { given for the cases }\end{array}$ & 164 & 151 & 315 \\
\hline 3 & $\begin{array}{l}\text { Number of adjournment given } \\
\text { unnecessarily }\end{array}$ & 85 & 52 & 137 \\
\hline 4 & $\begin{array}{l}\text { The actual adjournments to } \\
\text { render the judgment, if the } \\
\text { unnecessary grounds have been } \\
\text { not occurred }\end{array}$ & 72 & 99 & 171 \\
\hline
\end{tabular}

${ }^{31}$ Table 6: Other reasons of the delay in trials, the collected cases from the courts are the source of information in the table.

${ }^{32}$ Table 7: The number of cases examined and adjournment given thereof, the collected cases from the courts are the source of information in the table. 
The first adjournment was on 03/05/08E. $\mathrm{C}^{33}$ : on this date the defendants failed to appear before the court and the court ordered the police to bring them to the next adjournment.

The second adjournment 06/05/08: the first defendant cannot appear because of illness and the second defendant was not appeared. The court ordered the police with warning.

The third adjournment 10/05/08: on this date the second defendant was not appeared but the court proceeded to hear the case with the first defendant. The court ordered the police to bring the second one with serious warning.

The fourth adjournment 16/06/08: was not held because of meeting.

The fifth adjournment 24/06/08: the public prosecutor failed to produce evidence, the second defendant not able to appear.

The sixth adjournment 28/06/08: no evidence has been produced.

The seventh adjournment 01/07/08: no evidence has been produced.

The eighth adjournment 27/07/08: no evidence has been produced.

The ninth adjournment 30/07/08: evidence of the public prosecutor heard.

The tenth adjournment 30/07/08: the defendant sent free.

Under this case the seven adjournments out of the ten adjournments are unnecessary and create unreasonable delay. The case takes 113 dates, from the beginning of the case in the court. Because of the different reasons stated above the innocent defendant stayed in custody. If all the problems have been not occurred the case can be disposed within three adjournments and in a time less than a month.

File no. 33148

The case instituted on-8/11/06

Judgment rendered-19/12/07

Public prosecutor Vs. Solomon Boko

The defendant is accused under article 675 of the criminal code.

Under the file there are 20 adjournments and the case takes 397 days to render the final judgment. On the first adjournment the court ordered Dalle Prison to bring the accused to the next adjournment but they failed to do so. And the court ordered them for six consecutive adjournments and they remain silent. On the eighth adjournment the court ordered the official in charge of the prison to come and elaborate the reason why he failed to respect the orders of the court. But he didn't appear on the adjourned time and he appeared on the next adjournment and stated that "there is no one named Solomon Boko under our custody." The saddest part of this case is the statement of the official: Why he remains silent when the court gives 6 orders in the past 142 days? On this day the court give an order to the official to bring the accused for the next adjournment. Once again this order continues for the next 3 consecutive adjournments. At the end they brought the accused. After this event on the $13^{\text {th }}$ adjournment the accused failed to appear before the court, he has been released on bail. He

${ }^{33}$ Hereinafter all dates under this section are according to Ethiopian calendar. 
appeared on the $14^{\text {th }}$ adjournment however the public prosecutor failed to produce his evidences. After this adjournment the court takes only 6 adjournments and 63 days. This means the court has been in a position to render the judgment in a time less than 3 months, but the prison, the public prosecutor and the accused himself impeded the court from doing so.

File no. 31870

File instituted: 04/07/06E.C

File closed: 19/05/07

Total adjournment: 17

Result: the file closed without judgment because of the reason that defendant abscond from the region.

The defendant has been accused under article 693 of the criminal code-drawing of cheque without cover.

The first adjournment was on 22/07/06 but the defendant was not appeared and this condition was continued for the next two adjournments. On the fourth adjournment he appeared and the court allowed his release on bail. On the fifth adjournment the defendant was not appeared, but on the sixth one he requested to solve the case by restorative justice system and the court allowed. However for the next ten (10) adjournments the defendant disappeared and the court ordered the police uninterruptedly. Finally the police stated that the defendant absconded from Aroresa Woreda of Sidama Zone to Oromia Region and the court closed the file by notifying the right of the public prosecutor to institute the case in future. The last 315 days gone for nothing.

As per my view the court made a mistake in three ways: 1) if the court needs to close the case as of the final judgment it was possible to make it on the first three adjournments; 2) the court gave the bail right inappropriately because the accused shows his nature that it is unlikely that he will comply with the conditions laid down in the bail bond, which is the ground for the refusal of bail under article 67 of the criminal procedure code; 3 ) the court ran the case for 315 days with 17 adjournments for nothing. But there is an option to proceed with the case by sending a request for assistance in bringing back of the defendant. But the court failed to do so, for one or another reason.

\subsubsection{The Overall Performance of the Court under Selected Cases}

For the purpose of this section I selected 97 (ninety-seven) cases from Sidama Zone High Court, 33, 30 and 34 cases for 2006, 2007 and 2008 E.C, respectively. From these 97 cases the 41 are appeal cases and the remaining 56 cases are direct suit. To make a comparison with Hawassa City High Court there are 87 cases, all cases are direct suits, 24, 30 and 33 files for the years 2006, 2007 and 2008 E.C, respectively. No comparison is made with respect to appeal cases because there is almost similar performance at the disposition of appeal cases. The last three years, including this year, performance of the court is examined as follow:

\section{1) 2006 E.C}

All the selected 33 cases of 2006 takes 2366 days to render their final decision, 
20 direct suits 2044 days and 13 appeal cases 322 days. The court takes 102.2 days per case for direct suits and 24.769 days for appeal cases, the average day applied for all cases is 71.69 days. However, Hawassa City High Court takes 31.58 days per case for direct suits. For this 33 files the court gave 166 adjournments, 29 adjournment for the 13 appeal cases and 137 adjournment for the remaining 20 cases of direct suits, the average adjournment given for each appeal case is 2.23 and 6.85 for direct suits, the average adjournment for each of the 33 cases is 5.03. Whereas, Hawassa City High Court gave 4.58 adjournments per case. The court also gave 11.1 day gap between each adjournment under appeal cases and 14.92 days for the direct suits, the average day gap for the whole cases is 14.25 days, but the day gap between the adjournments of Hawassa City High Court is 6.89 days.

\section{2) 2007 E.C}

For the purpose of this year survey 30 cases are selected, 15 for each of direct suits and appeal cases. All the selected 30 cases of 2007 takes 2509 days to render their final decision, 15 direct suits 1980 days and 15 appeal cases 529 days. The court takes 132 days per case for direct suits and 35. 27 days for appeal cases, the average day applied for all cases is 83.63 days. However, Hawassa City High Court takes 52.33 days per case for direct suits. For this 30 files the court gave 147 adjournments, 42 adjournment for the 15 appeal cases and 105 adjournment for the remaining 15 cases of direct suits, the average adjournment given for each appeal case is 2.8 and 7 for direct suits, the average adjournment for each of the 30 cases is 4.9. Whereas, Hawassa City High Court gave 6.03 adjournment per case. The court also gave 12.59 day gap between each adjournment under appeal cases and 18.86 days for the direct suits, the average day gap for the whole cases is 17.06 days, but the day gap between the adjournments of Hawassa City High Court is 8.67 days.

\section{3) 2008 E.C}

For the purpose of this year survey 34 cases are selected, 13 appeal cases and 21 direct suits. All the selected 34 cases of 2008 takes 2258 days to render their final decision, 21 direct suits 1797 days and 13 appeal cases 461 days. The court takes 85.57 days per case for direct suits and 35. 46 days for appeal cases, the average day applied for all cases is 66.41 days. However, Hawassa City High Court takes 61.45 days per case for direct suits. For these 34 files the court gave 155 adjournments, 45 adjournment for the 13 appeal cases and 110 adjournment for the remaining 21 cases of direct suits, the average adjournment given for each appeal case is 3.46 and 5.23 for direct suits, the average adjournment for each of the 34 cases is 4.56 . Whereas, Hawassa City High Court gave 5.9 adjournment per case. The court also gave 10.25 day gap between each adjournment under appeal cases and 16.34 days for the direct suits, the average day gap for the whole cases is 14.57 days, but the day gap between the adjournments of Hawassa City High Court is 10.4 days.

Table 8 of the paper provides that the performance of the two courts under review with respect to the issue at hand. 
Table 8. The performance of the courts under selected cases.

\begin{tabular}{|c|c|c|c|c|c|c|c|c|c|c|c|c|c|}
\hline \multirow[t]{2}{*}{ Year } & \multirow[t]{2}{*}{ Type of the case } & \multicolumn{2}{|c|}{ Cases Selected } & \multicolumn{2}{|c|}{$\begin{array}{c}\text { The total days } \\
\text { devoted }\end{array}$} & \multicolumn{2}{|c|}{$\begin{array}{l}\text { Time devoted on } \\
\text { average }\end{array}$} & \multicolumn{2}{|c|}{ Total adjournment } & \multicolumn{2}{|c|}{$\begin{array}{c}\text { Average } \\
\text { adjournment for } \\
\text { each case }\end{array}$} & \multicolumn{2}{|c|}{$\begin{array}{l}\text { The day gaps } \\
\text { between each } \\
\text { adjournment }\end{array}$} \\
\hline & & $\begin{array}{c}\text { Sidama } \\
\text { Zone HC }\end{array}$ & $\begin{array}{c}\text { Hawassa } \\
\text { HC }\end{array}$ & $\begin{array}{c}\text { Sidama } \\
\text { Zone HC }\end{array}$ & $\begin{array}{c}\text { Hawassa } \\
\text { HC }\end{array}$ & $\begin{array}{c}\text { Sidama } \\
\text { Zone HC }\end{array}$ & $\begin{array}{c}\text { Hawassa } \\
\text { HC }\end{array}$ & $\begin{array}{c}\text { Sidama } \\
\text { Zone HC }\end{array}$ & $\begin{array}{c}\text { Hawassa } \\
\text { HC }\end{array}$ & $\begin{array}{c}\text { Sidama } \\
\text { Zone HC }\end{array}$ & $\begin{array}{c}\text { Hawassa } \\
\text { HC }\end{array}$ & $\begin{array}{l}\text { Sidama } \\
\text { Zone HC }\end{array}$ & $\begin{array}{c}\text { Hawassa } \\
\text { HC }\end{array}$ \\
\hline \multirow{2}{*}{2006} & Direct suits & 20 & 24 & 2044 & 758 & 102.2 & 31.58 & 137 & 110 & 6.85 & 4.58 & 14.92 & 6.89 \\
\hline & Appeal & 13 & -- & 322 & -- & 24.76 & -- & 29 & -- & 2.23 & -- & 11.1 & -- \\
\hline \multirow{2}{*}{2007} & Direct suits & 15 & 30 & 1980 & 1570 & 132 & 52.33 & 105 & 181 & 7 & 6.03 & 18.86 & 8.67 \\
\hline & Appeal & 15 & -- & 529 & -- & 35.26 & -- & 42 & -- & 2.8 & -- & 12.59 & -- \\
\hline \multirow{2}{*}{2008} & Direct suits & 21 & 33 & 1797 & 2028 & 85.57 & 61.45 & 110 & 195 & 5.24 & 5.9 & 16.34 & 10.4 \\
\hline & Appeal & 13 & -- & 461 & -- & 35.46 & -- & 45 & -- & 3.46 & -- & 10.25 & -- \\
\hline
\end{tabular}

\section{Conclusion and Recommendations}

\subsection{Conclusion}

The performance of Sidama Zone High Court has been assessed by this paper and we found out that the court renders judgment in a speedy manner for appeal cases because it gives very short adjournments with fewer adjournments in number. And the very interesting thing, with respect to this cases at the court, is the court gives an adjournment on the same day by giving one or two hours for the petitioning party to notify whether the case can be entertained by the appellate bench or not. Not only this but also the selected 41 appeal cases, for the last three years, took 32 days, on average, to render final decision. The court gave 2.82 adjournments per case with 11.35 days gap between each adjournment, that is the better performance and is the positive side of the court.

However, with respect to direct suits: the writer concludes that the Sidama Zone High Court is not delivering speedy trial for its clients. Because, as stated earlier, under chapter three, the number of cases and the number of the judges are not proportional, it rendered judgment, for direct suits, in 103.95 dates, on average for the last three years, this is longer time which is provided under the BPR document, it gives 16.54 dates between each adjournments, which is longer than the date given by its neighboring court, 8.96 dates between each adjournment. The court gives 6.28 adjournments for each case, on average; this one is also higher than the number of adjournments which is being given by the Hawassa City High Court, 5.58 adjournments per cases. Not only these $84.54 \%$ of the prisoners participated in the questionnaires, 82 out of 97 , whose case has been disposed by this court, in Hawassa Prison witnessed the court does not disposed their case in a speedy manner. ${ }^{34} 10.59 \%$ of the adjournments also made solely because of the problems related with the court and the court attributed for other adjournments by not applying the criminal procedure code appropriately.

\footnotetext{
${ }^{34}$ As per the number counted on May 26, 2016 there are 2167 male and 85 female prisoners in Hawassa Prison and the questioner has been distributed to 100 male and 15 female prisoners.
} 


\subsection{Recommendations}

Under this section the writer recommends the following measures to be taken by the court to achieve speedy trial, to respect the right of the accused.

$\checkmark$ The court shall close the files, with possible refilling of the case, within not more than three consecutive adjournments and not more than four adjournments at any proceedings of the whole case.

$\checkmark$ The court should avoid meetings on working hours.

$\checkmark$ Judges should consider the speedy trial right of the accused as competing interest whenever they give order on adjournments.

$\checkmark$ The court shall take measures on the official who fails to respect the orders given.

$\checkmark$ The Sidam Zone High Court shall recruit additional judges and judgment officers.

\section{Limitations}

The researcher, in the course of the study, has faced different challenges. Among others, shortage of time, unwillingness of the participants to participate in the study, difficulty to get interpreter of “Sidamigna” language, lack of knowledge on the part of majority of the participants on the subject matter of the study and shortage of reading materials have been the major challenges faced by the researcher. A researcher who need to study the area in the future is advised to implement more cases and population size under his/her questioner, so as to get more concrete result, because none of the information provided under this research are certain.

\section{Acknowledgements}

First of all, I would like to give my heartfelt thanks to my advisor, AtoShimeles Ashagre (LL. D. Candidate), for his concerned and constructive advice, and material support he extended to me for the successful accomplishment of this paper. All instructors of the law School of Hawassa University: this work is your interest from the knowledge you deposited in the bank of my mind, in the five years of my study at the University.

\section{References}

Defendant's Right to a Speedy Trial-Lawyers.com.html, Dec. 20, 2015.

FDRE (1961). Criminal Procedure Code of Ethiopia, Proclamation No. 185/1961.

FDRE (2005). The Criminal Code of the Federal Democratic Republic of Ethiopia, Proclamation No. 414/2004.

Garner, B. A. (1999). Black's Law Dictionary (7th ed.). St. Paul, MN: West Group.

http://www.lchr.org, Dec. 20, 2015.

http://www.thefreedictionary.com/_/WoD/rss.aspx.

https://en.wikisource.org/wiki/Constitution_of_the_Philippines_(1987)\#Article_III_Bill_ of_Rights, Jan. 12, 2016. 
Human Rights Committee, General Comment 13, Article 14 (Twenty-First Session, 1984). Compilation of General Comments and General Recommendations Adopted by Human Rights Treaty Bodies.

Interview with AtoGiremaGoye Share, The President of Sidama Zone High Court, Hawassa, 30 May 2016.

Interview with AtoYalewTsekeste, Public Prosecutor at Sidama Zone Justice Office, 19 May 2016.

Lawyers Committee for Human Rights (2000). What Is A Fair Trial? A Basic Guide to Legal Standards and Practice.

Nowak, M. (1993). U.N. International Covenant on Civil and Political Rights. ICCPR Commentary.

Right to a Speedy Jury Trial-FindLaw.html, Jan. 11, 2016.

Robinson, P. (2009). The Right to a Fair Trial in International Law: With Specific Reference to the Work of the ICTY (Vol. 3). Berkeley J.L Int'l L. Publicist.

United Nations (1948). Universal Declaration on Human Rights (UDHR).

United Nations (1966). International Covenant on Civil and Political Rights (ICCPR).

United Nations (1966). International Covenant on Economic, Social and Cultural Rights (ICESCR). 


\section{Appendix 1. Questionnaires Employed in the Data Collection}

\section{A Questioner for Prisoners at Hawassa Prison Administration}

The objectives of following questions of the questioner are to get decisive imputes to a research that the researcher conducts on the right to speedy trial. The researcher, therefore humbly request you to personally look at the questions and kindly deliver the answers that you think to be proper.

1) Which court entertained your case in first instance capacity?
A) Sidama zone first instance courts
B) Hawasaa city first instance court
C) Sidama zone high court
D) Hawassa city high court

2) How long the court takes to give final decision on your case
A) Less than a month
B) One up to 3 months
C) 3 up to 6 months
D) 6 months up to 1 year
E) 1 year up 2 years
F) More than 2 years
3) Do you get a speedy trial?
A) Yes
B) No
C) I don't know

4) If your response for question number 3 is no, what do you think is the cause to that? (you can choose more than one choice)
A) The court has limited number of judges
B) The judges are not competent enough
C) The existence of corruption and other unethical practices
D) Nonappearance of witnesses of the public prosecutor
E) Nonappearance of defense witnesses
F) Failure of judges to comply with the rules of procedural laws
G) Any other
5) Which court reviewed your case in appellate jurisdiction?
A) Sidama zone high court
B) Hawassa city high court
C) The supreme court of the regional state
D) Any other, if any
E) I did no appeal
6) How long the appellate court takes to decide your case?
A) Less than a month
B) One up to 3 months
C) 3 up to 6 months
D) 6 months up to 1 year
E) 1 year up 2 years 
F) More than 2 years

7) Do you think that you get a speedy trial in this appellate court?

A) Yes, I think

B) No, I don't think

C) I don't know

8) If your response for question number 7 is no, what do you think is the cause to that? (you can choose more than one choice)

A) The court has limited number of judges

B) The judges are not competent enough

C) The existence of corruption and other unethical practices

D) Nonappearance of witnesses of the public prosecutor

E) Nonappearance of defense witnesses

F) Failure of Judges to comply with the rules of procedural laws

G) Any other

9) Have you ever missed to appear to court on a day of your adjournment because of failure of the prison administration to present you?
A) Yes, I did
B) No, I did not
C) I don't remember center) to present you?
A) Yes, I did
B) No, I did not
C) I don't remember

10) Have you ever missed to appear before court on a day of your adjournment because of failure of the police station (while you were in police detention

\section{A Questioner for Court Clients}

The objectives of following questions of the questioner are to get decisive imputes to a research that the researcher conducts on the right to speedy trial. The researcher, therefore humbly request you to personally look at the questions and kindly deliver the answers that you think to be proper.

1) With what case you come to this court?
A) Criminal
B) Civil
A) Less than a week
B) 1 up to 2 weeks
C) 2 weeks up to a month
D) 1 up to 2 months
E) 2 up to 4 months
F) 4 up to 6 months
G) 6 up to 1 year
H) 1 up to 2 years
I) More than 2 years

2) How long your case is in this court? 
3) Do you think the court is delivering a speedy trial in your case?
A) Yes, I think
B) No, I don't think
C) I don't know

4) If your response for question number 3 is no, what do you think is the cause to that? (you can choose more than one choice)
A) The court has limited number of judges
B) The judges are not competent enough
C) The existence of corruption and other unethical practices
D) Nonappearance of witnesses of the public prosecutor
E) Nonappearance of defense witnesses
F) Failure of Judges to comply with the rules of procedural laws
G) Any other

\section{Questioner for Suspects Detained in Sidama Zone Police Detention Centers}

The objectives of following questions of the questioner are to get decisive imputes to a research that the researcher conducts on the right to speedy trial. The researcher, therefore humbly request you to personally look at the questions and kindly deliver the answers that you think to be proper.

1) When did you come to this police station?
A) 1 up to10 days
B) 10 up to 15 days
C) 15 up to 20 days
D) 20 days up to 1 month
E) More than 1 month
2) Have you been taken to a court?

A) Yes

B) No, I did not

3) If your answer question number 2 is yes, how many times you did?

4) Do you know which crime you are convicted with?
A) Yes
B) No
5) Do you receive your criminal charge?

A) Yes

B) No

6) How many days were between your first and the subsequent adjournment? (please provide the gaps of each adjournments if you appeared several times?)

7) Do you think that you are getting a speedy trial in this court?
A) Yes, I think
B) No, I don't think
C) I don't know 
8) If your response for question number 7 is no, what do you think is the cause to that? (you can choose more than one choice)

A) The court has limited number of judges

B) The judges are not competent enough

C) The existence of corruption and other unethical practices

D) Nonappearance of witnesses of the public prosecutor

E) Nonappearance of defense witnesses

F) Failure of Judges to comply with the rules of procedural laws

G) Any other

\section{Appendix 2. Interview Guide Prepared for the Data Collection}

\section{Interview Guide for the President of Sidama Zone High Court}

1) Do you think that you are delivering speedy trial?

2) What are your measurements to this speedy trial?

3) Have ever have a client application for not getting speedy trial?

4) If so, what solution do you give?

5) How many adjournments do you think the court must give in case the prosecutor fails to bring his witness or the police fails to present the suspect?

6) In how long time you think criminal cases are getting final decisions?

7) Do you think the judges that the court has are sufficient and competent enough?

\section{Interview Guide for Sidama Zone High Prosecutor}

1) How long it takes when a certain case is disposed in a speedy manner?

2) What about a case that took a lengthy period?

3) Do you think that you are delivering a speedy trial for your clients?

4) What are your measurements to this speedy trial?

5) Is there any client who files an application claiming that he did not get speedy trial?

6) Is there any way through which courts check whether or not you are doing your works properly?

7) To request transfer of adjournment, what is your parameter to determine the length of the time?

8) Have you ever failed to bring your witness to the court? If yes, what are the reasons?

9) What kind of supports do you have for accused persons so that they can bring their defense evidences? 